On the positive connection between success and happiness

Uusiautti, Satu $\bowtie$

University of Lapland, Finland (satu@ uusiautti.fi)

Received: 25 June 2013

Available Online: 20 November 2013

Revised: 15 October 2013 DOI: $10.5861 /$ ijrsp. 2013.509

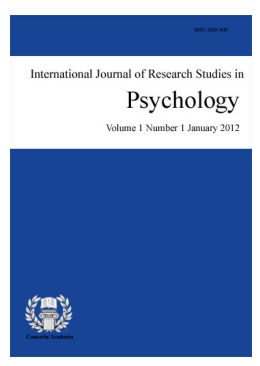

Accepted: 16 October 2013

ISSN: $2243-7681$ Online ISSN: 2243-769X

OPEN ACCESS

\title{
Abstract
}

The concept of success is manifold but might contribute an interesting viewpoint to the current discussion of human flourishing and positive development. In this paper, the author introduces a viewpoint and a definition that connects success with happiness. When considered from this perspective, success consists of various elements, competence, motivation, performance, and positive strategies. When people can use their talents and strengths, are motivated in doing and have the courage to seize opportunities, they also have positive experiences and the sense of purpose in life. Success is not therefore any particular phase of life but a manifestation of the combination of necessary elements of success that are closely connected with human happiness.

Keywords: success; happiness; competence; motivation; performance; positive psychology 


\section{On the positive connection between success and happiness}

\section{Introduction}

Not long ago, I was interviewed to a Finnish afternoon paper about success and its preconditions in life. I was supposed to give my opinion on several claims about success, for example whether it was dependent on genes (referring to talent and intelligence), luck (lucky coincident and opportunities), background factors (parents' social status, environment), or hard work and practicing, or whether success was something that just accumulates: those who have good prerequisites succeed the best. I as a specialist, having accomplished a PhD in education and studied success among awarded employees of the year (Uusiautti, 2008), was asked to give my professional opinion from the viewpoint of an educator as one of three experts in different fields. I was happy to comment on these arguments but simultaneous it came clear that the concept of success can be considered from so many points of view and obviously we three experts commenting on the arguments did not agree on the definition. This gave me the impetus to write about my perspective. On the one hand, my purpose was to study the definition of success, but on the other hand, I wanted to contribute to the discussion of human flourishing and well-being (see also Seligman, 2011).

In this paper, I will analyze the concept of success from a particular point of view. My purpose is to explain my viewpoint to it and open up the fundamental idea of considering success something positive. Now, I am aware of that most people already think success is something positive - naturally, it has a positive connotation. Successful people have achieved something worth pursuing for in some or many areas of life. But in what way is it positive? Is success manifested in some other, perhaps material, ways? Does it mean that the one having success is also happy? Could it mean that?

In this article, I will discuss success as a form of positive human development. What does that mean? I will start by introducing some key ideas and concepts that I think support my idea of success. This review is based on my previous research on positive human development and success and the purpose is to draw a theoretical compilation of the findings.

\section{People Strive for Success}

Success can be considered the fullest expression of mastery at any areas of life (Krueger, 1990; see also Uusiautti, 2008). However, the concept is not that easily approachable: what factors can form the elements of success? When conducting research on success (Uusiautti, 2008; 2013; Uusiautti \& Määttä, 2010; 2011; 2012), certain psychological concepts that foster positive emotions that are acquired through feelings of mastery and inner drive could form the core of success. Indeed, there are numerous theories that explain the connection between mastery and performance that can be viewed from the point of view of success. Psychological research is filled with various concepts defining human action, motives, and outcomes of these, all can be seen as manifestation of mastery and performance, but the suggestion here is that their common nominator, the umbrella term, could be success.

Naturally, there are also outer factors that have influence on all the aforementioned states and behaviors. For example, encouraging learning environments, loving parents, or supportive workplaces are likely to enhance one's success, while underestimating, oppressive, or unstable environments are likely to hinder such positive development (Uusiautti \& Määttä, 2013). Therefore, this review will also include a viewpoint of how the individual person's success in always also context-bound. Next, I will introduce these concepts in detail. They are partly overlapping and interconnected, in other words, they complement each other and form such a combination that can form the heart of success. 


\subsection{Success is about Competence}

Originally, White (1959) used the concept of competence to describe a person's ability to act efficiently in his or her environment. In order to do that, development thus means acquiring greater competence, and the subjective side of competence is the sense of competence. Deci and Moller (2005) view the concept from the perspective of motivation psychology and have complemented White's thoughts by adding the need for competence as one dimension of competence. The term intrinsic motivation refers to this need. Later, Deci and Ryan (2008), have shown that autonomous motivation predicts persistence and adherence and is advantageous for effective performance. Furthermore, this is shown to be related to psychological health.

Adler (1982) made an early definition of the elements of competence, and it provides a good way of analyzing the multidimensional nature of the concept. Perhaps the most important element of an individual's competence is the ability to perform social roles that the community and society set for each and every one of us. The second element is self-conception. A competent person has a stable and well-developed identity that includes awareness of one's strengths and weaknesses, an optimistic conception of the relationship with the surrounding world, and a realistic understanding of one's possibility of controlling one's own destiny. The third element consists of interaction skills. People need necessary interaction skills that are communication, credibility and reliability, sensitivity and empathy, and negotiation skills. The fourth element is the ability to regulate emotions, especially the negative one, such as fear, frustration, anger, and guilt, and to learn to recognize and control inappropriate reactions to these emotions. The fifth dimension of competence is the ability to develop and move from one developmental stage to another. The sixth element refers to the ability to cope with stressful experiences, life crises, and other events that one cannot prevent or influence. The seventh element is the ability to acquire such resources that one needs in order to pass a certain phase. Cognitive skills form the last element of competence. It refers to the ability to work with words, concepts, and symbols, and process information. Causal thinking and planning, and understanding of the social reality and social problem-solving skills are important areas of competence (Adler, 1982).

Competence also is related to how people perceive their control over their activities and tasks (e.g., Paulsson, Ivergård, \& Hunt, 2005). Karasek's (see Karasek \& Theorell 1990) model of work-control shows that in situations where people have a high-strain job with high demands and low control, they cannot meet the challenges efficiently. On the other hand, a low-strain job with low demands and high control enables optimal responses to challenges but the job is not likely to cause satisfaction or well-being. Passive job has low control and low mental strain: people can feel that their skills and abilities are not in best use and misspent. The state of indifference and lack of challenges can expand to other areas of life too, as people lose their courage to develop and test their skills. In active jobs, people have plenty of mental strain but also high control. They can use their abilities which is, for example, likely to lead to the experience of flow (Csikszentmihalyi, 2008; Csikszentmihalyi, Abuhamdeh, \& Nakamura, 2005).

When considered from the point of view of success, competence combined with opportunities to actively use their skills and strengths-whether it was at work, in leisure, at school, in parenting, etc.-could be one of the core elements of success. Naturally, it is also about the person himself or herself and whether he or she is ready to seize challenges.

\subsection{Success is about Motivation}

The role of motivation was already mentioned in the previous section as it is one of the core elements of competence. Indeed, motivation is also a crucial element of success, too. Fundamentally, motivation can be considered a critical factor in any theory attempting to predict and explain behavior and performance (Mitchell, 1997).

Intrinsic motivation describes the need for learning new and develop toward greater autonomy, competence, 
and self-determination. It also includes the structure of personality and development of motivation. Action that is intrinsically motivated is experienced valuable as such: action has an intrinsic attribution and thus it does not threaten the feeling of autonomy. This leads to satisfaction and positive experiences. Moreover, intrinsic motivation is not regulated by extrinsic rewards or punishments but doing becomes self-purposeful (Ryan \& Deci, 2000a; 2000b).

The positive experience connected to motivation and doing is worth further investigation. For example, already in the 1990s, Locke and Latham (1990) introduced a theory in which they combined work motivation and work satisfaction, and called the model "high performance cycle". The cycle started by giving an employee a challenging task. If the challenge includes expectancy of success, high performance is guaranteed assuming that the employee is engaged to the goal, receives adequate feedback, and situational factors do not affect the performance considerably. Similar findings have been learned from the various education levels (e.g., Gilpin, 2009; Green et al.., 2012; Oades et al., 2011) and hobbies (e.g., Carruthers \& Hood, 2005), too.

\subsection{Success is about Good Performance}

This idea is basically based on the finding that positive experiences regarding to one's doing make one of the most central dimensions of a good performance (Uusiautti, 2008; Uusiautti \& Määttä, 2011; see also Liden, Wayne, \& Sparrowe, 2000). It is important to analyze what might the core concepts that help understanding the positive experience of doing. Competence is often confused with performance, but actually, they are not any synonyms (Kanfer \& Ackerman, 2005). Namely, competence refers to a more stable state or to a person's characteristic. Performance is a momentary happening and can vary depending on many factors even if competence was high in relation to the task at hand.

Kanfer and Ackerman (2005) distinguish two dimensions of performance: maximal and typical performance. The former refers to a person's skills and abilities and describes all that the person can do when inner states (e.g., sleep, concentration, etc.) are optimal and when it is possible to concentrate on the task. The latter dimension is typical behavior referring to how the person usually does things or how he or she is likely to perform. The researchers point out that although maximal performance is an interesting research target, it would perhaps be more beneficial to pay attention to the difference between what the person can do and what he or she actually does. In Kanfer and Ackerman's (2005) model, performance consists of various factors that are abilities, skills and knowledge, personality, motivation, and self-image. Motivation affects through personal interest and general motivational tendencies. The performance lays the foundation for a learning mechanism that is connected to features that increase competence (see also Stoltenberg, 2005).

The concept of self-efficacy is also closely related to competence and performance. Self-efficacy means a person's assessment of his or her own abilities to use his or her resources and regulate his or her behavior in order to perform a task (Judge, Locke, \& Durham, 1997; Mitchell, 1997; Caprara \& Cervone, 2006). It is therefore similar to the aforementioned sense of competence. It has been shown that positive self-efficacy improves a person's performance and well-being in numerous ways (Schunk \& Pajares, 2005). People who have high self-efficacy devote to their activities more and are more perseverance than who estimate their competence weaker. In addition, people with high self-efficacy are likely to select more high-level goals and engage to them (Bandura, 1997; Mitchell, 1997).

\subsection{Success is about Positive Strategies}

Although top performances or steady, quality performing can lead to success, it can also be considered from a more comprehensive process. Namely, people who want to develop and seize opportunities of life can be considered following a positive strategy. This is an interesting perspective to the phenomenon of success. Carver and Scheier (2005) have pointed out that it is also important that people realize when goals can be met and when it is time to give up. Ultimately, it is about the ability to estimate the situation and act accordingly. Likewise, 
expectations toward the future greatly affect how people react to changes and challenges. Optimistic attitude has a salient role (Carver \& Scheier, 2002) but the strategy of success can be described in other ways too.

For example, Locke (2002) claims that success needs constant trying. One has to think what is the desirable goal and why, what kinds of intermediate goals should be set, how to reach the goal, how to prioritize demands that are contradictory in relation to the goal, how to overcome future obstacles and setbacks- how to achieve the outcome one has dreamed of?

Baltes and Freund (2006; see also Freund \& Baltes, 1998) refer to SOC model which provides a general framework for the understanding of developmental change and resilience across the life span. The fundamental idea is that people's lives are filled with opportunities and limitations that can be "mastered adaptively an orchestration of three components: selection, optimization, and compensation" (Freund \& Balter, 1998, p. 531). On the other hand, Covey (2006) considered success as a strategy in which knowledge, skills, and will are combined. Knowledge answers the question of what to do and why. Skills can make it happen whereas will is a synonym for motivation or need for achieving something. As these three dimensions meet such a strategy that leads to success can emerge.

Naturally, constant pursue for success can lead to an endless treadmill. The theory of hedonic treadmill (see Brickman, Coates, \& Janoff-Bulman, 1978; Diener, Lucas, \& Napa Scollon, 2006) claims that people constantly try to get a happier life because they believe that greater happiness waits right around the next corner, after achieving the next goal or solving the next problem. Happiness and success are there but not yet ever reached. And on the other hand, people are somewhat happy all the time (Myers \& Diener, 1995).

\subsection{Success happens in Context}

Even though one had the most exquisite competence and high motivation, one still functions in a certain time and place. Behavior depends on its context and its outcome. In addition, contexts are dynamic and change during an individual's life span (Baltes \& Freund, 2006). However, according to self-determination theory (SDT), people are by nature active and self-motivated, curious and interested, vital and eager to succeed because success itself is personally satisfying and rewarding (Deci \& Ryan, 2008).

Magnusson and Mahoney (2006) present four theses about the nature of phenomena when dissecting positive development and that can be considered relevant for the conceptualization of success too. First, the individual acts and develops as an active, intentional part of the integrated, multidimensional, dynamic, and adaptive person-environment system. The nature of this system changes along the life span through developmental processes, societal changes, and as a result of constant individual-environment interaction processes. Second, the individual develops along the course of time as an integrated, undivided organism within the multidimensional, dynamic, and adaptive maturing and learning process. This interaction process involves mental, biological, and behavioral factors of the individual, and social, cultural, and physical features of the environment. Third, the preconditions provided by the environment, including the possibilities, limitations, demands, and expectations, are especially important to the research on positive development. Fourth, the theoretical model that aims at explaining the model that direct a human being's positive development, has to include and integrate the individual's mental, biological, and behavioral aspects, and the physical, social, and cultural aspects of the individual's environment (Magnusson \& Mahoney, 2006).

These viewpoints highlight felicitously the basic idea of positive development and success too. Positive development cannot be defined without referring to the individual, but merely, the attention must be paid on the natural features, resources, and limitations within his or her cultural, physical, and historical context (Magnusson $\&$ Mahoney, 2006).

What this means is that success, when considered from this positive point of view, also needs to be seen in context: first of all, the processes have a holistic nature which means that success is a result of a functional 
interaction of its elements merely than how each element influence on the entity. Second, the inner processes, such as mental, biological, and behavioral functions, and outer processes, such as opportunities, obligations, and rules, and how well these processes are synchronized contribute to the possibility of success.

It is therefore relevant to ask whether positively acting people's life spans differ from others' life spans and if they do, how. Basically, the discussion of the phenomenon of success tries to analyze how it can be enhanced, what are the ways of conceptualizing it as positive development, and most importantly open discussion of how the elements can be recognized. This paper introduces one way of seeing success.

\section{Discussion}

\subsection{Can Success be about Happiness?}

Before introducing the combination of the aforementioned dimensions of success, I want to highlight one interesting theory of personal happiness. Dr. Seligman (2002) distinguishes three kinds of levels in happiness: (1) pleasure and gratification, (2) embodiment of strengths and virtues, and (3) meaning and purpose. He (Seligman, 2002) states that while the pleasant life might bring more positive emotion to one's life, to foster a deeper more enduring happiness, we need to explore the realm of meaning. Without the application of one's unique strengths and the development of one's virtues towards an end bigger than one's self, one's potential tends to be whittled away by a mundane, inauthentic, empty pursuit of pleasure. (p. 160)

The point in Seligman's thoughts is profound and far-reaching: he argues that through using of signature strengths people can have a meaningful life. Having a meaningful life is connected therefore to authentic happiness. Why people are happy when using their strengths? The answer is because they have the sense of ownership and authenticity, and feelings of excitement, invigoration, joy, zest, and enthusiasm (Seligman, 2002, p. 160). When feeling such positive emotions and having the desire of using these strengths people also feel happy.

Likewise, instead of focusing on problems and stress-factors of today's life, I wanted to focus this conceptual review on the positive sides of human behavior, development, and success (see also Almost $\&$ Spence Laschinger, 2002; Spence Laschinger, Finegan, Shamian, \& Wilk, 2004). Figure 1 illustrates the interconnectedness of the elements introduced above.

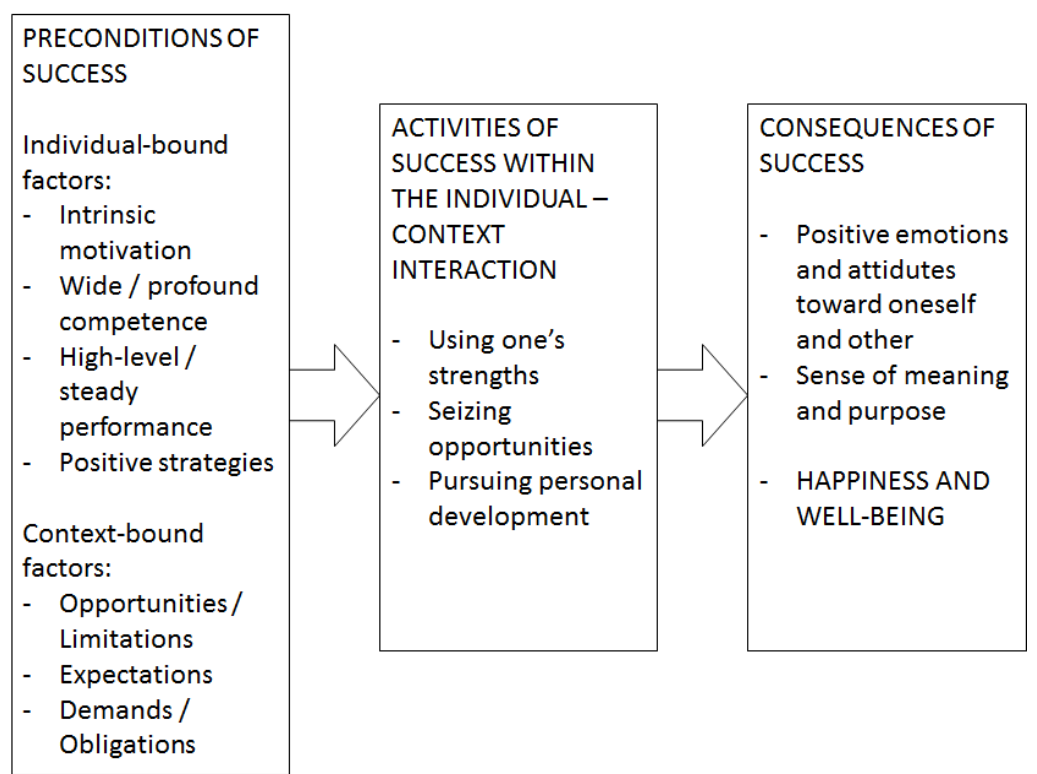

Figure 1. The elements of success and their interconnectedness 
The fundamental idea of this illustration is that success is (1) depended on certain factors, (2) necessitates action, and (3) is manifested through certain outcomes. The first section means that success at any areas of life can consist various elements that can be divided roughly into individual-bound factors and context-bound factors. They form the preconditions of success. However, success is not just a state of soon to be happen, but it requires action. Likewise, certain motivational and contextual have a salient role in the process as they are also closely connected with sense of capability or self-efficacy (see e.g., Duda \& Nicholls, 1992). When it comes to the background factors and their significance in the process, for example Uusiautti and Määttä (2013, p. 69) have concluded that "experiences and events taking place in childhood and adolescence can be crucial, or at least, direct people in a right direction" (p. 69) when talking about positive development and the background factors of success. So the push toward success can be a sum of many factors causing the sense of purposeful doing and thus the sense of finding the right path. It means that when the individual-bound and context-bound features are synchronized (see also Magnusson \& Mahoney, 2006), the individual can seize the opportunities, use his or her strengths, and actively pursues for personal development. What is the result then? Success in this perspective is manifested as positive emotions and attitudes, which means a good feeling of oneself, one's capability, and one's place in the world. This kind of sense of purpose and meaning are core of happiness (see Seligman, 2002).

In sum, success is considered a combination of feelings of expertise, competence, and accomplishments, top performances, and the use of positive strategies (see Uusiautti, 2008, 2013; Uusiautti \& Määttä, 2010, 2011) within the context. Therefore, success is not defined as the achievement of a certain goal or position in life (e.g., becoming a top pianist or a CEO). Merely success is achievable by anyone who discovers his or her strengths, finds the motivation to use them, applies positive strategies, but also realizes the opportunities and limitations of the context. This viewpoint does not close the eyes to mistakes, hardships, or poor conditions. The question is merely about the realization that success can be understood positively, as a means of positive development and way to well-being and happiness at their fullest, and that success requires action and personal effort, too. Although success has context-bound features, it is also quite individualistic when seen as a manifestation of personal growth, effort, and good outcomes.

Let us take an example. When considered a person's success, one has to be competent in that particular area-may that be for example school mathematics. Competence and ability to learn are not enough but one also has to have the motivation to learn and use mathematics. Then, in order to be successful in mathematics, one has to perform well in that area. The fourth dimension adds a longitudinal aspect to success, that being positive strategies. In order to be successful in mathematics at school, one has to possess necessary skills to optimize one's development in mathematics by aiming at learning as widely as possible to become a straight-A student in math or figuring out a difficult task. All this happens in context: the person can be encouraged, supported, taught, and mentored by parents, friends, relatives, or teachers. The school can apply mathematics curriculum that enhances the mathematics-enthusiastic pupil's skills and he or she seizes the opportunities of using the math talent. Success in math eventually can lead to the positive feeling about oneself as a whole, ignite optimistic attitude toward one's chances and the future: mathematics could be something one could continue working with in later life too. This is the foundation of success. When these areas overlap, the person can develop and grow to his or her fullest, use his or her strengths, have positive experiences and the sense of purpose in life. For the aforementioned mathematics-enthusiast being able to learn about math and use mathematical talents, find pleasure and joy from learning and working with math, and then finding it important and meaningful can provide him or her with such positively-toned success that becomes a source of happiness that can be found by finding the strengths and interests, and applying them actively in life.

\section{Conclusion}

\section{Happiness as the By-product of Pursuit of Success}

Now, it seems that success considered from the viewpoint presented here has a connection with happiness. Why is it important to talk about happiness? Happiness is not only important to individual people themselves 
but it also benefits the surrounding society (Gilpin, 2008). According to numerous studies on happiness, happy people have been shown to be open, courageous, trusting, and helpful (Seligman et al., 2005; see also Gilpin, 2008); friendly and non-materialistic (see e.g., Fishbach \& Labroo, 2007; Otake et al., 2006; Polak \& McCullough, 2006); and cooperative, pro-social, benevolent, and "other-centered" (Lyubomirsky, Sheldin, \& Schkade, 2005). The positive feeling of using one's strength is ultimately connected to authenticity. This is where strengths and authentic experiences are connected to happiness and well-being. But they are also connected to another phenomenon: namely success.

As happiness, also success is always a subjective, personal experience, and personal achievements are evaluated in different ways (Maddux, 2002). However, this theoretical analysis on success wanted to highlight that we need to understand what are those cognitive and motivational processes that maintain and even increase positive spirit and emotions important to for example problem-solving skills and innovative action (Isen, 2001; 2003) and happiness (see also Lyubomirsky, 2001; Ojanen, 2001).

Perceiving the phenomenon of success from this perspective is relevant to many areas of life, but especially remarkable is that the foundation of success can be laid already in the childhood. Positive psychology is interested in finding and creating optimal conditions for all children and students (Carruthers \& Hood, 2005). Success is not just something that for example gifted people are entitled to but the concept could be used for enhancing everyone's success. If the mastery of information or skill that students need to learn leads to success, and if positive emotions make one of the corner stones of successful learning, it would be reasonable to pay attention to this viewpoint in education (Chafouleas \& Bray, 2004). The purpose is to research, define, and specify human strengths and capacities that individual people, families, communities, and societies should aim at making use of. Positive human development should be encouraged (Dunn et al., 2008), and the suitable goal might be to have everyone benefit from the happiness advantage (see Anchor, 2010).

\section{References}

Adler, P. T. (1982). An analysis of the concept of competence in individuals and social systems. Community Mental Health Journal, 18(2), 34-45. http://dx.doi.org/10.1007/BF00757110

Almost, J., \& Spence Laschinger, H. K. (2002). Workplace empowerment, collaborative work relationships, and job strain in nurse practitioners. Journal of the American Academy of Nurse Practitioners, 14(9), 408-420. http://dx.doi.org/10.1111/j.1745-7599.2002.tb00142.x

Achor, S. (2010). The happiness advantage. The seven principles of positive psychology that fuel success and performance at work. New York, NY: Randon House.

Baltes, P. B., \& Freund, A. M. (2006). Ihmisen vahvuudet ja viisaus [The human strengths and wisdom]. In L. G. Aspinwall \& U. M. Staudinger (Eds.), Ihmisen vahvuuksien psykologia [A psychology of human strengths] (pp. 34-46). Helsinki: Edita.

Bandura, A. (1997). Self-efficacy: the exercise of control. New York, NY: Freeman.

Brickman, P., Coates, D., \& Janoff-Bulman, R. (1978). Lottery winners and accident victims: Is happiness relative? Journal of Personality \& Social Psychology, 36(8), 917-927. http://dx.doi.org/10.1037/0022-3514.36.8.917

Caprara, G. V., \& Cervone, D. (2006). Persoonallisuus toimivana, itsesäätelevänä järjestelmänä [Personality as functional, self-regulatie system]. In L. G. Aspinwall \& U. M. Staudinger (Eds.), Ihmisen vahvuuksien psykologia [A psychology of human strengths] (pp. 69-82). Helsinki: Edita.

Carruthers, C., \& Hood, C. D. (2005). The power of positive psychology. Parks \& Recreation, Oct 2005, 30-37.

Carver, C. S., \& Scheier, M. F. (2002). Optimism. In C. R. Snyder \& S. J. Lopez (Eds.), Handbook of positive psychology (pp. 231-243). Oxford: Oxford University Press.

Carver, C. S., \& Scheier, M. F. (2005). Engagement, disengagement, coping, and catastrophe. In A. J. Elliot \& C. S. Dweck (Eds.), Handbook of competence and motivation (pp. 527-547). New York \& London: The Guilford Press.

Chafouleas, S. M., \& Bray, M. A. (2004). Introducing positive psychology: finding a place within school 
psychology. Psychology in the Schools, 41(1), 1-6. http://dx.doi.org/10.1002/pits.10133

Covey, S. R. (2006). Tie menestykseen. 7 toimintatapaa henkilökohtaiseen kasvuun ja muutokseen [Road to success. 7 methods of personal growth and change]. (5th ed.) Jyväskylä:Gummerus.

Csikszentmihalyi, M. (2008). Flow. The psychology of optimal experience. $\left(10^{\text {th }} \mathrm{ed}\right.$.) New York, NY: HarperPerennial.

Csikszentmihalyi, M., Abuhamdeh, S., \& Nakamura, J. (2005). Flow. In A. J. Elliot \& Carol, S. Dweck (Eds.), Handbook of competence and motivation (pp. 598-608). New York \& London: The Guilford Press.

Deci, E. L., \& Moller, A. C. (2005). The concept of competence. A starting place for understanding intrinsic motivation and self-determined extrinsic motivation. In A. J. Elliot \& C. S. Dweck (Eds.), Handbook of competence and motivation (pp. 579-597). New York \& London: The Guilford Press.

Deci, E. L., \& Ryan, R. M. (2008). Facilitating optimal motivation and psychological well-being across life's domains. Canadian Psychology, 49(1), 14-23. http://dx.doi.org/10.1037/0708-5591.49.1.14

Diener, E., Lucas, R. E., \& Napa Scollon, C. (2006). Beyond the hedonic treadmill. Revising the adaptation theory of well-being. American Psychologist, 61(4), 305 - 314. http://dx.doi.org/10.1037/0003-066X.61.4.305

Duda, J. L., \& Nicholls, J. G. (1992). Dimensions of achievement motivation in schoolwork and sport. Journal of Educational Psychology, 84(3), 290-299. http://dx.doi.org/10.1037/0022-0663.84.3.290

Dunn, D. S., Uswatte, G., \& Elliott, T. R. (2008). Happiness, resilience, and positive growth following physical disability. In J. S. Lopez \& C. S. Snyder (Eds.), Oxford handbook of positive psychology (pp. 651-664). Oxford: Oxford University Press.

Fishbach, A., \& Labroo, A. A. (2007). Be better or be merry: how mood affects self-control. Journal of Personality and Social Psychology, 93(2), 158-173. http://dx.doi.org/10.1037/0022-3514.93.2.158

Freund, A. M., \& Baltes, P. B. (1998). Selection, optimization, and compensation as strategies of life management: Correlations with subjective indicators of successful aging. Psychology and Aging, 13(4), 531-543. http://dx.doi.org/10.1037/0882-7974.13.4.531

Gilpin, J. M. (2008). Teaching happiness. The role of positive psychology in the classroom. Pell Scholars and Senior Theses, 12, 1-23.

Green, J., Liem G. A., Martin, A. J., Colmar, S., Marsh, H. W., \& McInerney, D. (2012). Academic motivation, self-concept, engagement and performance in high school: key processes from a longitudinal perspective. Journal of Adolescence, 35(5), 1111-1122. http://dx.doi.org/10.1016/j.adolescence.2012.02.016

Isen, A. M. (2001). Some perspectives on positive affect and self-regulation. Psychological Inquiry, 11(3), 184-187.

Isen, A. M. (2003). Positive affect as a source of human strength. In L. G. Aspinwall \& U. M. Staudinger (Eds.), A psychology of human strengths. Fundamental questions and future directions for a positive psychology (pp. 179 - 196). Washington, DC: American Psychological Association. http://dx.doi.org/10.1037/10566-013

Judge, T. A., Locke, E. A., \& Durham, C. C. (1997). The dispositional causes of job satisfaction. Research in Organizational Behavior, 19, 151-188.

Kanfer, R., \& Ackerman, P. L. (2005). Work competence: a person-oriented perspective. In A. J. Elliot \& C. S. Dweck (Eds.), Handbook of competence and motivation (pp. 336-353). New York \& London: The Guilford Press.

Karasek, R., \& Theorell, T. (1990). Healthy work. Stress, productivity, and reconstruction of working life. New York, NY: Basic Books.

Krueger, D. W. (1990). Success and Success Inhibition. In R. J. Sternberg \& J. Kolligian Jr. (Eds.), Competence considered (pp. 246-260). New Haven, CN: Yale University Press.

Liden, R. C., Wayne, S. J. \& Sparrowe, R. T. (2000). An examination of the mediating role of psychological empowerment on the relations between the job, interpersonal relationships, and work outcomes. Journal of Applied Psychology, 85(3), 407 - 416. http://dx.doi.org/10.1037/0021-9010.85.3.407

Locke, E. A. (2002). Setting goals for life and happiness. In C. R. Snyder \& S. J. Lopez (Eds.), Handbook of 
positive psychology (pp. 299-312). Oxford: Oxford University Press.

Locke, E. A., \& Latham, G. P. (1990). Work motivation and satisfaction: light at the end of the tunnel. Psychological Science, 1(4), 240-246. http://dx.doi.org/10.1111/j.1467-9280.1990.tb00207.x

Lyubomirsky, S. (2001). Why are some people happier than others? The role of cognitive and motivational processes in well-being. American Psychologist, 56(3), 239-249. http://dx.doi.org/10.1037/0003-066X.56.3.239

Lyubomirsky, S., Sheldin, K. M., \& Schkade, D. (2005). Pursuing happiness: the architecture of sustainable change. Review of General Psychology, 9(2), 111-131. http://dx.doi.org/10.1037/1089-2680.9.2.111

Maddux, J. E. (2002). Self-efficacy. The power of believing you can. In C. R. Snyder \& S. J. Lopez (Eds.), Handbook of positive psychology (pp. 277-287). Oxford: Oxford University Press.

Magnusson, D., \& Mahoney, J. L. (2006). Holistinen lähestymistapa myönteisen kehityksen tutkimuksessa [Holistic approach in research of positive development]. In L. G. Aspinwall \& U. M. Staudinger (Eds.), Ihmisen vahvuuksien psykologia [A psychology of human strengths] (pp. 232-250). Helsinki: Edita.

Mitchell, T. R. (1997). Matching motivational strategies with organizational contexts. Research in Organizational Behavior, 19, 57-149.

Myers, D. G., \& Diener, E. (1995). Who is happy? Psychological Science, 6(1), 10-19. http://dx.doi.org/10.1111/j.1467-9280.1995.tb00298.x

Oades, L. G., Robinson, P., Green, S., \& Spence, G. B. (2011). Towards a positive university. The Journal of Positive Psychology: Dedicated to furthering research and promoting good practice, 6(6), 432-439.

Ojanen, M. (2001). Ilo, onni, hyvinvointi [Joy, happiness, well-being]. Helsinki: Kirjapaja.

Otake, K., Shimai, S., Tanaka-Matsumi, J., Otsui, K., \& Fredricsson, B. L. (2006). Happy people become happier through kindness: a counting kindnesses intervention. Journal of Happiness Studies, 7(3), 361-375. http://dx.doi.org/10.1007/s10902-005-3650-z

Paulsson, K., Ivergård, T., \& Hunt, B. (2005). Learning at work: competence development or competence-stress. Applied Ergonomics, 36, 135-144. http://dx.doi.org/10.1016/j.apergo.2004.09.008

Polak, E. L., \& McCullough, M. E. (2006). Is gratitude an alternative to materialism. Journal of Happiness Studies, 7, 343-360. http://dx.doi.org/10.1007/s10902-005-3649-5

Ryan, R. M., \& Deci, E. L. (2000a). Self-determination theory and the facilitation of intrinsic motivation, social development, and well-being. American Psychologist, 55(1), 68-78. http://dx.doi.org/10.1037/0003-066X.55.1.68

Ryan, R. M., \& Deci, E. L. (2000b). When rewards compete with nature: the undermining of intrinsic motivation and self-regulation. In C. Sansone \& J. M. Harackiewicz (Eds.), Intrinsic and extrinsic motivation. The search for optimal motivation and performance (pp. 14-54). Thousand Oaks, CA: Academic Press. http://dx.doi.org/10.1016/B978-012619070-0/50024-6

Schunk, D. H., \& Pajares, F. (2005). Competence perceptions and academic functioning. In A. J. Elliot \& C. S. Dweck (Eds.), Handbook of competence and motivation (pp. 85-104). New York \& London: The Guilford Press.

Seligman, M. E. P. (2002). Authentic happiness. New York, NY: Free press.

Seligman, M. E. P., Steen, T. A., Park, N., \& Peterson, C. (2005). Positive psychology progress. Empirical validation of interventions. American Psychologist, 60(5), 410-421. http://dx.doi.org/10.1037/0003-066X.60.5.410

Seligman, M. E. P. (2011). Flourish. A visionary new understanding of happiness and well-being. New York, NY: Free Press.

Spence Laschinger, H. K., Finegan, J. E., Shamian, J., \& Wilk, P. (2004). A longitudinal analysis of workplace empowerment on work satisfaction. Journal of Organizational Behavior, 25, 527-545. http://dx.doi.org/10.1002/job.256

Stoltenberg, C. D. (2005). Enhancing professional competence through developmental approaches to supervision. American Psychologist, 6, 857-864. http://dx.doi.org/10.1037/0003-066X.60.8.85

Uusiautti, S. (2008). “Tänään teen elämäni parhaan työn” Työmenestys Vuoden Työntekijöiden kertomana ['Today, I'll work better than ever" Success at work described by the employees of the year]. (PhD Diss, 
University of Lapland, Rovaniemi, Finland).

Uusiautti, S. (2013). An action-oriented perspective on caring leadership: a qualitative study of higher education administrators' positive leadership experiences. International Journal of Leadership in Education: Theory and Practice, online first 6 March 2013.

Uusiautti, S., \& Määttä, K. (2010). What kind of employees become awarded of the Year in Finland? Enterprise and Work Innovation Studies, 6, 53-73.

Uusiautti, S. \& Määttä, K. (2011a). Love for work as the way towards well-being. Global Journal of Human Social Science, 11(9), 63-68.

Uusiautti, S., \& Määttä, K. (2011b). The process of becoming a top worker. International Education Studies, 4(4), 69-79. http://dx.doi.org/10.5539/ies.v4n4p69

Uusiautti, S., \& Määttä, K. (2013). Brisk attitude and optimism - Top workers' childhood experiences forming the basis of success at work. European Journal of Educational Research, 2(2), 69-82.

White, R. W. (1959). Motivation reconsidered: the concept of competence. Psychological Review, 66(5), 297-333. http://dx.doi.org/10.1037/h0040934 
Uusiautti, S. 